\title{
Challenges Faced by the Employees towards Industrial Relations at V.O.Chidambaranar Port Trust, Thoothukudi
}

\section{R. Samundeswari}

\begin{abstract}
Industrial Relations are close relationship of management, employees and Government for industrial or non-industrial. In the context of Industrial Relations any Individual relationship with the management by the workers are not taken as industrial relations Industrial relations are considered to be an important part of the industrial growth and development. The current study is carried out with the reason to find out the challenges faced by the employees towards industrial relations in the V.O.Chidambaranar Port Trust.
\end{abstract}

Keywords : Industrial Relations, Management, Trade Union.

\section{INTRODUCTION}

Industrial relations prove to be a part ofsocio-economic aspect of the economy. It is a dynamic process relating to the point of socio-economic. It is a designation of complete field of relationship that exist because of the necessary relationship of men and women in the employment processes of industry. Industrial relations is a multidisciplinary field that studies the employment relationship existing in an industry. Industrial relations is also called as employment relations or employee relations because of the significance of non-industrial employment relationships. This fact is sometimes seen as further extension of the human resource management trend. Indeed, some authors now speak out on human resource management as synonymous with employee relations. Other authors envision employee relations as one which deals with only with non-unionizedworkers, whilelabour relations is seen as dealing with unionized workers.Industrial relations study, examine various employment situation, not just ones withan unionized workforce.

\section{OBJECTIVES OF THE STUDY}

- To study the problems related with work environment and welfare facilities.

- To study the problems related with management.

- To study the problems related with trade union.

\section{SAMPLING DESIGN}

A sample of 400 employees were selected on the basis of
Proportionate Random Sampling technique.

\section{ANALYSIS AND FINDINGS OF THE STUDY}

Table 1: Problems Related to Working Environment and Welfare Facilities

\begin{tabular}{|c|c|c|c|c|c|c|}
\hline \multirow[b]{2}{*}{$\begin{array}{l}\text { SI. } \\
\text { No. }\end{array}$} & \multirow[b]{2}{*}{ Descriptive } & \multicolumn{4}{|c|}{ Mean Score of Employees } & \multirow{2}{*}{$\begin{array}{c}\mathrm{F} \text { - } \\
\text { Statistics }\end{array}$} \\
\hline & & $\begin{array}{l}\text { Super } \\
\text { visor }\end{array}$ & Clerks & Labours & Overall & \\
\hline 1. & $\begin{array}{l}\text { Poor maintenance of toilets, } \\
\text { washing points and dustbins }\end{array}$ & 3.65 & 3.53 & 3.99 & 3.88 & $24.78 * *$ \\
\hline 2. & $\begin{array}{l}\text { No drinking water facilities } \\
\text { at department wise }\end{array}$ & 3.65 & 3.51 & 3.98 & 3.88 & $18.48 * *$ \\
\hline 3. & No crèche facilities & 3.50 & 3.42 & 3.98 & 3.85 & $26.10 * *$ \\
\hline 4. & $\begin{array}{l}\text { Employees children } \\
\text { education facilities are not } \\
\text { satisfactory }\end{array}$ & 3.95 & 3.23 & 3.98 & 3.82 & $35.00 * *$ \\
\hline 5. & $\begin{array}{l}\text { Availability of recreational } \\
\text { facilities are Not satisfactory }\end{array}$ & 3.82 & 3.82 & 3.29 & 3.31 & $1.4 \mathrm{NS}$ \\
\hline 6. & $\begin{array}{l}\text { Incentives and fringe } \\
\text { benefits offered to the } \\
\text { employees are quite poor }\end{array}$ & 3.02 & 3.33 & 3.76 & 3.62 & $16.79 * *$ \\
\hline 7. & $\begin{array}{l}\text { Inadequate non-monetary } \\
\text { benefits like awards, Club } \\
\text { membership }\end{array}$ & 3.15 & 3.17 & 3.58 & 3.47 & $7.19 * *$ \\
\hline 8. & $\begin{array}{ll}\begin{array}{l}\text { Inadequate } \\
\text { programme }\end{array} & \text { training } \\
\end{array}$ & 3.40 & 4.98 & 4.14 & 3.89 & $42.28 * *$ \\
\hline 9. & $\begin{array}{l}\text { Most of the welfare facilities } \\
\text { were bestowed by the } \\
\text { management on its own } \\
\text { accord }\end{array}$ & 3.00 & 2.60 & 3.06 & 2.99 & $4.71 * *$ \\
\hline 10. & $\begin{array}{l}\text { Dissatisfaction with strength } \\
\text { of residence doctor }\end{array}$ & 3.02 & 2.80 & 3.25 & 3.16 & $5.53^{* *}$ \\
\hline 11. & $\begin{array}{l}\text { Insufficient reimbursement } \\
\text { of residence doctor }\end{array}$ & 3.37 & 3.23 & 3.85 & 3.71 & $13.68 * *$ \\
\hline 12. & $\begin{array}{l}\text { Lack of guidance and } \\
\text { counseling }\end{array}$ & 3.32 & 3.53 & 3.56 & 3.53 & $0.92 \mathrm{NS}$ \\
\hline 13. & $\begin{array}{l}\text { Lack of career advancement } \\
\text { facilities }\end{array}$ & 3.30 & 3.22 & 3.77 & 3.66 & $11.71 * *$ \\
\hline 14. & $\begin{array}{l}\text { Inadequate sports and } \\
\text { recreational facilities }\end{array}$ & 3.30 & 3.33 & 3.77 & 3.67 & $8.14 * *$ \\
\hline 15. & $\begin{array}{lll}\begin{array}{l}\text { Inadequate benefits } \\
\text { dependents }\end{array} & \text { for } \\
\end{array}$ & 3.32 & 3.44 & 3.49 & 3.46 & $0.82 \mathrm{NS}$ \\
\hline 16. & $\begin{array}{l}\text { Inadequate incentives and } \\
\text { bonus }\end{array}$ & 3.17 & 3.52 & 3.70 & 3.62 & $7.66^{* *}$ \\
\hline
\end{tabular}

Source: Computed by the researcher

Sixteen statements pertaining to the problems faced by the employees, the labours have a high perception on 'Inadequate training programme' the mean score of 4.140 which implies that the problem with work environment and welfare to upgrade in tune with, working environment welfare facilities is an important problem for them. The supervisors and clerical category of employees have a high perception of 'Availability of recreational facilities are not satisfactory' since the mean score of 3.819 and 3.820 . 
The significant difference among the three categories of employees is identified regarding the perception on the thirteen statements related to the work environment and welfare facilities since the respective the significant level of F-statistics is at 5 percent level.

Table 2: Problems Related to Management

\begin{tabular}{|c|c|c|c|c|c|c|}
\hline \multirow{2}{*}{$\begin{array}{l}\text { SI. } \\
\text { No. }\end{array}$} & \multirow{2}{*}{ Descriptive } & \multicolumn{4}{|c|}{ Mean Score of Employees } & \multirow{2}{*}{$\begin{array}{c}\mathrm{F}- \\
\text { Statistics }\end{array}$} \\
\hline & & $\begin{array}{c}\text { Superviso } \\
\text { rs }\end{array}$ & Clerks & Labours & Overall & \\
\hline 1. & $\begin{array}{l}\text { Disputes in the pay } \\
\text { anomaly }\end{array}$ & 3.05 & 3.07 & 3.10 & 3.09 & $0.10 \mathrm{NS}$ \\
\hline 2. & $\begin{array}{l}\text { Insufficient bonus } \\
\text { statutory minimum rate } \\
\text { of } 8.33 \% \text { only }\end{array}$ & 3.15 & 3.12 & 3.10 & 3.12 & $0.06 \mathrm{NS}$ \\
\hline 3. & $\begin{array}{l}\text { Communication is not } \\
\text { proper }\end{array}$ & 3.22 & 3.32 & 3.78 & 3.65 & $13.85^{* *}$ \\
\hline 4. & $\begin{array}{l}\text { Inequality in work load } \\
\text { assigned }\end{array}$ & 3.96 & 3.68 & 3.30 & 3.85 & $10.43^{* *}$ \\
\hline 5. & $\begin{array}{l}\text { Superior- Subordinate } \\
\text { co-operation not good }\end{array}$ & 3.40 & 3.53 & 4.16 & 3.99 & $33.05^{* *}$ \\
\hline 6. & $\begin{array}{l}\text { The relationship among } \\
\text { co-workers not good }\end{array}$ & 3.42 & 3.48 & 3.97 & 3.84 & $19.64 * *$ \\
\hline 7. & $\begin{array}{l}\text { There is no } \\
\text { compassionate ground } \\
\text { and new appointment } \\
\text { are nowadays }\end{array}$ & 3.32 & 3.38 & 3.57 & 3.52 & $2.39 \mathrm{NS}$ \\
\hline 8. & $\begin{array}{ll}\text { Grievances } & \text { settlement } \\
\text { are delayed } & \end{array}$ & 3.52 & 3.78 & 3.43 & 3.70 & $3.57^{*}$ \\
\hline 9. & $\begin{array}{ll}\text { No } & \text { employee } \\
\text { counseling } & \end{array}$ & 3.45 & 3.37 & 4.44 & 4.18 & $81.25^{* *}$ \\
\hline 10. & $\begin{array}{l}\text { Workers participation } \\
\text { in Management is not } \\
\text { satisfactory }\end{array}$ & 3.57 & 3.32 & 4.26 & 4.05 & $58.33 * *$ \\
\hline
\end{tabular}

Source: Computed by the researcher

Ten statements pertained to the level and importance of the problems, the labours perceive highly of all the statements defining the problem with a mean score of 3.100, $3.100,3.776,3.300,4.160,3.973,3.573,3.433,4.443$ and 4.263 respectively in the order of the statements presented in the table above. The supervisors and clerical employees also perceive highly of the two problems 'Inequality in workload assigned' and 'Grievances settlement isdelayed'. Labour employees perceive highly of the two problems 'No employee counselling' and 'Workers participation in management is not satisfactory'. With regard to the problem "Superior-Subordinate co-operation not good" the supervisors and clerks categories have a low perception with mean scores of 3.400 and 3.533 respectively whereas the labours perceive highly of this statement. Perhaps the labour employees are the main sufferers due to the above-mentioned statements.

The significant difference among the three categories of employees is identified regarding the perception on the seven statements problems related with management since the respective F-statistics is significant at 5 percent level.

Table 3: Problems Related to Trade Union

\begin{tabular}{|c|c|c|c|c|c|c|}
\hline \multirow{2}{*}{$\begin{array}{l}\text { SI } \\
\dot{\mathrm{N}} \\
\text { o. }\end{array}$} & \multirow[b]{2}{*}{ Descriptive } & \multicolumn{4}{|c|}{ Mean Score of Employees } & \multirow[b]{2}{*}{$\begin{array}{c}\text { F- } \\
\text { statistics }\end{array}$} \\
\hline & & $\begin{array}{c}\text { Superv } \\
\text { isors }\end{array}$ & Clerks & Labours & Overall & \\
\hline 1. & $\begin{array}{l}\text { Some unions are not acting } \\
\text { satisfactory }\end{array}$ & 3.45 & 3.30 & 4.35 & 4.10 & $77.871^{* *}$ \\
\hline 2. & $\begin{array}{l}\text { Unions have failed to realize } \\
\text { the importance of mutual help } \\
\text { and Welfare activities }\end{array}$ & 3.37 & 3.28 & 3.87 & 3.72 & $14.07 * *$ \\
\hline 3. & $\begin{array}{l}\text { Low membership fee and } \\
\text { unsound financial position } \\
\text { may discourage Union from } \\
\text { undertaking welfare activities }\end{array}$ & 3.27 & 2.86 & 3.47 & 3.36 & $10.29 * *$ \\
\hline 4. & $\begin{array}{l}\text { The multiplicity of a trade } \\
\text { union has affected the } \\
\text { efficient functioning of unions }\end{array}$ & 3.22 & 2.90 & 3.38 & 3.29 & $6.76^{* *}$ \\
\hline 5. & $\begin{array}{l}\text { Inter-union rivalry affects the } \\
\text { interest of the workers }\end{array}$ & 3.67 & 3.16 & 3.97 & 3.82 & $22.73 * *$ \\
\hline 6. & Still, they fight for the basic & 3.52 & 3.37 & 3.87 & 3.76 & $15.17 * *$ \\
\hline
\end{tabular}

Source: Computed by the researcher necessity like bonus, wages

and leave

Six statements pertained to the level and importance of the problem related to trade union, the labours perceive highly of all the statements defining the problems with mean scores of $4.350,3,873,3.473,3.383,3.970$ and 3.870 respectively in the order of the statements presented in the table above. The supervisors and clerical employees also perceive highly of the problems 'Some unions are not acting satisfactorily', 'Inter-union rivalry affects the interest of the Workers' and 'Still they fight for the basic necessity like a bonus, wages and leave'.

The significant difference among the three categories of employees is identified regarding the perception on all above six statements related to the problem with the tradeunion since the respective F-statistics is significant at 5 percent level.

\section{CONCLUSION}

It is the duty of the Governmentis to balance the contradictory interest in Labour and Management and this relationalways proves to be difficult task, in view of mutually contradictory interests of labour and management. The basicproblems of industrial relations are of permanent in nature and a permeant solution to this can be a bigger challenge for the years to come. Certain norms and principles can be used as guidelines in facing the situations and dealing with problem of industrial relations. Policy of the Government and laws on industry can play an important ormajor role in the process of determining the structure of industrial relations. Industrial relations a crucial part of any industry in enacting or shaping the economic growth and as well the industry making it fit to the current ear. The future of any industry depends on the better and efficient management of Industrial Relations.

\section{REFERENCES}

1. Dale Yonder, Personnel Management and Industrial Relations, New Jersey, Prentice Hall Inc.1965,

2. Goyal R.C, Determinants of Industrial Relations, XII, Indian Journal of Labour Economics,

3. Pallavikumar, Problem and Prospect of Industrial Relations in Coal Industry with special reference to C.C.L. Ranchi, Journal of Multidisciplinary Research, Vol. 2, June 2013.

4. Obisi Chris, The Changing role of state in Industrial Relations and social protection, Journal of Management Research, Vol. 9, April 2017.

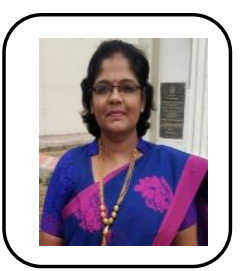

\section{AUTHOR PROFILE}

Dr. R. Samundeswari M.Com., M.Phil., SET. Ph.D.. Assistant Professor of Commerce in A.P.C. Mahalaxmi College for Women, Thoothukudi. She received the Ph.D degree in Commerce from Manonmaniam Sundaranar University in 2019. Her research interest includes Human Resource Management, Banking and Marketing. 